\author{
Available online at http:// bajas.edu.iq \\ https://doi.org/10.37077/25200860.2019.275 \\ College of Agriculture, University of Basrah
}

Basrah Journal of Agricultural Sciences

ISSN 1814 - 5868 Basrah J. Agric. Sci., 32 (Spec. Issue 2): 272-282, 2019

E-ISSN: 2520-0860

\title{
The Effect of Moringa oleifera Leaf Meal and their Aqueous and Ethanolic Extracts on Immunological Parameters, and Liver Enzymes of Broiler Chickens
}

\author{
Hassan H. Hussein ${ }^{1}$ \& Jaffer M. Jassim²
}

${ }^{1}$ Agriculture Directorate of Maysan, Iraq

${ }^{2}$ Department of Animal Production, Collage of Agriculture, University of Basrah, Iraq

*Corresponding author e-mail: alihhss1960@ gmail.com

Received 19 September 2019; Accepted 18 November 2019; Available online 22 November 2019

\begin{abstract}
The purpose of this study is to investigate the effect of Moringa oleifera leaf meal and their aqueous and ethanolic extracts on immunological parameters, economic results and liver enzymes of broiler chickens. Two hundred and ten unsexed day-old Ross308 broiler chicks were divided into seven experimental diets . Each treatment had three replicates with 10 birds per replicate. Each replicate was fed with an assigned experimental diet for five weeks. The treatments were as follows:T1 was the control without addition, T2 adding $2 \mathrm{~g}$ M. oleifera Leaf Meal (MOLM)/kg of feed, T3 adding $4 \mathrm{~g}$ M. oleifera Leaf Meal (MOLM). $\mathrm{kg}^{-1}$ feed, T4 adding $2 \mathrm{ml}$ Moringa Aqueous Leaf Extract (MALE) each 1 litre water, T5 adding $4 \mathrm{ml}$ Moringa Aqueous Leaf Extract (MALE) each 1 litre water, T6 adding $2 \mathrm{ml}$ Moringa Ethanolic Leaf Extract (MELE)each 1 litre water, T7 adding $4 \mathrm{ml}$ (MELE) each 1 litre water. The results showed there was a significant decrease $(\mathrm{P}<0.05)$ in the weights of the bursa gland of moringa treatments in a comparison with control group. While the addition of moringa did not have any significant effect on relative weights of spleen and on the ratio of heterophils to lymphocytes $(\mathrm{H} / \mathrm{L})$ in the blood of broilers. There was no significant difference in the values of liver enzymes (AST and ALT) among M. oleifera treatments and control.
\end{abstract}

Keywords: Moringa oleifera, Aqueous extract, Ethanolic extract, Broiler.

\section{Introduction}

Poultry is a popular industry because it enjoys a relative advantage of easy management, higher income, quick returns to capital investment and wide acceptance of its products for human consumption (Haruna \& Hamidu, 2004). Poultry plays a very important role in the humans' food supply, income, and employment generation and providing grew materials to some industries. The increase in the prices of conventional feeding redients is a major factor affecting net return to the poultry business (ElBanna \& Atef, 2016). This is because $70-75 \%$ of the total cost of poultry operation is incurred on feeding (Mahmood et al., 2005). One of the challenges facing poultry farmers is the issue of diseases and infection. This has caused a high rate of mortality and lack of productivity in poultry production (Alikwe et al., 2016). In developing countries, average daily protein intake of human diets is well below recommended standards, and the poultry production is playing a major role to fill this 
gap (Hassan et al., 2017). Plant products have been used for centuries by humans as food and to treat ailments. Natural medicinal products originating from herbs and spices have also been used as feed additives for farm animals (Guo, 2003). Among the ingredients, protein supplements are very expensive; therefore; it is necessary to look for alternative sources available locally for use as a protein supplement in poultry feed. Using leaf sources as a protein ingredient in broiler's diet is getting attention due to availability, abundance and relatively reduced cost (Onyimonyi \& Onu, 2009). According to Fasuyi et al. (2008) leaf meal does not serve only as protein sources but also provides some necessary vitamins, minerals and also oxy-carotenoid which causes yellow colour of broiler skin, shank and egg yolk.

The use of chemical feeds additives as growth promoters have criticism due to adverse effects on consumers and there is increasing demand for organic meat and egg (Agashe et al., 2017). Some medicinal plant products are known to enhance natural resistance of hosts of infection due to the presence of bioactive phytochemicals or phytonutrients (Soetan \& Oyewole, 2009). Antibiotic growth promoters (AGP) have been used as poultry feed additives to enhance gut health, control sub-clinical diseases and improving the growth performance of poultry such as increasing body weight gain and improving feed conversion ratios (Alcicek et al., 2003). Furthermore, medication in water using antibiotics helps birds to recover from diseases (Khalafalla et al., 2010). However, the benefit of the use of antibiotics as growth promoters has some disadvantages such as drug toxicity, residual effects, and development of bacteria resistance (Ogbe \& John, 2012).
Moringa Moringa oleifera leaves are reported to have potential prebiotic effects and potentially anti-oxidant phytochemicals, such as chlorogenic acid and caffeic acid (Siddhuraju \& Becker, 2003). M. oleifera is one of the plants that can be utilized in the preparation of poultry feeds (Makker \& Becker, 1999). The plant apart from being a good source of vitamins and amino acids that has medicinal uses (Francis et al., 2005). M. oleifera, otherwise regarded as a "miracle trees" has been used in the treatment of numerous diseases (Gbasi et al., 2000). M. oleifera leaf meal, widely available in many tropical countries, is also a good source of antioxidant compounds such as ascorbic acid, flavonoids, phenolic, and carotenoids (Teixeira et al., 2014). The leaves of the moringa tree have been reported to have an antioxidant activity due to the higher amount of polyphenols (Sreelatha \& Padma, 2009; Moyo et al., 2012).

M. oleifera leaves are a rich source of vitamins. Its leaf meal may be a promising source of natural antioxidants for broiler meat (Makker \& Becker.,1996). It also possesses antimicrobial activity due to its principle component which removes free radicals, activates antioxidant enzymes and inhibits oxidases (Luqman et al., 2012). Moringa is a multi-purpose tropical tree and it has been dubbed the "miracle tree" or "trees of life" in popular media (Bosch et al., 2004; Radovich, 2013; FAO, 2014) mainly because it is used for food and has numerous industrial, medicinal and agricultural uses, including animals feeding. Moringa leaves have been reported to be a rich source of $\beta$-carotene, protein, vitamin $\mathrm{C}$, calcium and potassium and act as a good source of natural antioxidant compounds such as flavonoids, phenolic, and carotenoids (Anwar \& Bhanger, 2003). 
It is one of the herbs containing biomedical agents that could substitute synthetic growth enhancers and supplements with broilers and other livestock production since it possesses important medicinal properties which include antibacterial and anti-fungal activities (Nickon et al., 2008). The importance of $M$. oleifera in ethno botany as health remedies the anti-microbial property of crude extracts and anti-nutritional factors particularly saponins can be removed through solvent and aqueous extractions of the petals of $M$. oleifera that has been studied as part of the exploration for new and novel bioactive compounds (Makkar \& Becker, 1997; Richter et al., 2003).

The objective of this study was to determine the effect of $M$. oleifera leaf meal and their aqueous and ethanolic leaf extract on immunological parameters, economic results and liver enzymes of broiler chickens.

\section{Materials \& Methods}

This study was carried out at the farm of The Animal Production Department, Agriculture
College, University of Maysan. Two hundred and ten unsexed day-old Ross308 broiler chicks were divided into seven experimental diets in a Complete Randomized Design (CRD). Each treatment had three replicates with 10 birds per replicate. Each replicate was fed with an assigned experimental diet for a period of five weeks. The birds were purchased from Al- Barakat Hatchery in AlAmarah City with an average initial body weight (40) $g$ and reared under similar managerial conditions by using the floor breeding system. The experimental diets and drinking water was supplied to the birds ad libitum. Throughout the study period, the recommended routine medication and vaccination programs were observed. The lighting system was artificial for 24 hours. The ventilation was naturally achieved by opening and closing windows in addition to using fans for drawing a vicious air. The nutrition was free through experimental periods and the feed intake was recorded daily.

\section{Immunological traits}

Relative weight of interior bowels $=\frac{\text { Organ weight }(\mathrm{gm})}{\text { Live body weight }(\mathrm{gm})} \times 100 \quad$ (Alfayaz \& Naji, 1989)

Account of fibrcus gland index $=\frac{\text { Ratio of gland weight to the body weight of defined treatment }}{\text { Ratio of gland weight to the body weightof control treatment }} \times 100$ (Naji, 1996)

Account of percentage Heterophils/ Lymphocytes

H/ L Ratio $=\frac{\text { No.of Hetrophils in } 100 \text { White cell }}{\text { No.of Lymphocytes in } 100 \text { White cell }} \times 100$

(Shen \& Patterson, 1983)

\section{Liver enzymes}

\section{Measurement activity of AST enzyme}

The activity concentrating of the enzyme which carrier to the AST (GOT) Amine in blood plasma by Kit supply from Bio lab. technical support. The analysis were action according to the an information of prepared company. The absorbency sample and the standard solution were measure by spectrophotometer on the wave length 500 nanometre (Reitman \& Frankel, 1975). 


\section{Measurement activity of ALT enzyme}

The activity concentrating of the enzyme which carrier to the ALT Amine in blood plasma by Kit supply from Bio meri Eux. The analysis were action according to the an information of prepared company. The absorbency sample and the standard solution were measure by spectrophotometer on the wave length 500 nanometre (Kind \& King, 1954).

\section{Nutrition}

It was used two diets throughout the experimental period. First, the starter diets from 7 to 17 days. The metabolic energy was (2936) $\mathrm{kcal} / \mathrm{kg}$ feed and the crude protein percentage (22.26\%). The second was a finisher diet and it's given to birds from 18 to the end of this study at 35 days. It contains (3118) ) kcal/kg feed as metabolic energy and $(20.20 \%)$ the percentage of the crude protein. The feed ingredient purchased from the local market, and broilers were given the experimental diets from the end of the first week (table 1).

Table (1) Percentage composition of the starter experiment and broiler diets.

\begin{tabular}{lcc}
\hline Feed ingredient & Starter diet $\%(7-17)$ days & $\begin{array}{c}\text { Finisher diet \% (18-35) } \\
\text { days }\end{array}$ \\
\hline Maize & 54 & 58 \\
\hline Wheat bran & 9 & 0 \\
\hline Wheat & 0 & 22 \\
\hline Soya bean meal 44\% & 25 & 8 \\
\hline Protein concentrate* & 10 & 1 \\
\hline Vegetable oil & 1 & 0.50 \\
\hline Lime stone & 0.50 & 0.25 \\
\hline Salt & 0.25 & 0.25 \\
\hline Premix & 0.25 & 100 \\
\hline Total & 100 & 3118 \\
\hline & Calculating chemical analysis ** & \\
\hline Metabolic energy $(\mathrm{k}$ cal/ & 2936 & 0.821 \\
kg) & & 154.36 \\
\hline Crude protein \% & 23.26 & 4.78 \\
\hline ME/ CP Ratio & 131.90 & 3.30 \\
\hline Crude Fat \% & 4.90 & 0.88 \\
\hline Crude Fiber \% & 4.13 & 0.35 \\
\hline Ca \% & 1.02 & 1.14 \\
\hline Available P \% & 0.50 & 0.73 \\
\hline Lysine \% & 1.32 & \\
\hline Methionine + Cystine \% & 0.80 & \\
\hline
\end{tabular}

$* \square$ Cp 40\%, ME $2000 \mathrm{kcal} / \mathrm{kg}$, C. fiber 3\%, EE 3\%, Ash 34\%, Ca 8\%, Av. P 1.38\%, Lysine 12\%, Methionine 3\%, Methionine + Cystine

3.5\%. Vitamin A $250000 \mathrm{IU} / \mathrm{kg}$, Vitamin D3 $50000 \mathrm{IU} / \mathrm{kg}$, Vitamin E $500 \mathrm{mg} / \mathrm{kg}$, Vitamin K3 $60 \mathrm{mg} / \mathrm{kg}$, Vitamin B1/Thiamin 20

$\mathrm{mg} / \mathrm{kg}$, Vitamin B2/Riboflavin $100 \mathrm{mg} / \mathrm{kg}$, Niacin Vitamin PP $600 \mathrm{mg} / \mathrm{kg}$, Pantothenic acid/Vitamin B3 $160 \mathrm{mg} / \mathrm{kg}$, Vitamin 
B6/Pyridoxine 40 mg/kg, Vitamin B12 300 mcg/kg, Biotin/Vitamin H 2000 mcg/kg, Choline 10000 mg/kg, Vitamin C $4000 \mathrm{mg} / \mathrm{kg}$,

Folic Acid 30 mg/kg, Iron 800 mg/kg, Manganese 1400 mg/kg, Copper 120 mg/kg, Zinc $1000 \mathrm{mg} / \mathrm{kg}$, Iodine 6 mg/kg, Cobalt 12

$\mathrm{mg} / \mathrm{kg}$, Selenium $3 \mathrm{mg} / \mathrm{kg}$

** According to the chemical analysis (NRC, 1994) .

\section{Experimental treatments}

The study included seven treatments and each treatment had three replicate with 10 birds per replicating as follows:- T1 (controls without addition), $\mathrm{T} 2$ adding $2 \mathrm{~g}$ M. oleifera leaf meal (MOLM). $\mathrm{kg}^{-1}$ of feed, T3 adding 4 $\mathrm{g}$ (MOLM). $\mathrm{kg}^{-1}$ of feed, T4 adding $2 \mathrm{ml}$ Moringa Aqueous Leaf Extract (MALE) each 1 litre water, T5 adding $4 \mathrm{ml}$ (MALE) each 1 litre water, T6 adding $2 \mathrm{ml}$ Moringa Ethanolic Leaf Extract (MELE) each 1 litre water, T7 adding $4 \mathrm{ml}$ (MELE) each 1 litre water.

\section{Preparation materials using in experimental treatments}

\section{M. oleifera Leaf Meal}

The green leaves of $M$. oleifera were purchased from a local orchard in Abu Al-
Khaseeb city, Basrah Governorate at early flowering stages. Branches were cut from the Moringa trees, spread out and dried under the shade for a period of 4 to 5 days. Thereafter, branches were threshed carefully to separate leaves from twigs before milling and also removed by hand. The dried leaves were ground with hammer mills to make a leaf meal. The leaf meals were stored in the plastic bags during entire periods of the study. A small amount of meal was dried by putting it in electric oven for 4 hours at $105 \mathrm{C}^{\circ}$ in the nutrition laboratory of Animal Production Department, College of Agriculture, University of Basrah. Then the percentage of humidity, dry matter, ash, and other parameters were evaluated according to special methods. The results showed in table (2).

Table (2): The composition of $M$. oleifera leaf meal.

\begin{tabular}{lc}
\hline Parameters & Percentage composition $(\%)$ \\
\hline Moisture & 06.26 \\
\hline Dry matter( DM) & 93.74 \\
\hline Crude protein & 26.31 \\
\hline Ether extract & 2.440 \\
\hline Total ash & .7008 \\
\hline Crude fiber & 16.08 \\
\hline Nitrogen free extract & 40.21 \\
\hline
\end{tabular}

\section{Aqueous leaf extract}

Fresh leaves of the plant were air-dried under normal environmental conditions. The airdried leaves were ground before extraction and soaked in distilled water for 24 hours using ratio 1:2 (weight/volume). The preparation was then filtered to separate the debris and filtrate using Whitman's filter paper. The filtrate was collected, the solvent was removed using a rotary evaporator and the residue obtained after evaporation was weighed. The concentrated stock solution of Moringa leaf extracts was prepared by dissolving $50 \mathrm{~g}$ of the residue in 1 litre of sterile distilled water and stored at $40{ }^{\circ} \mathrm{C}$. The 
concentrated extract at calculated doses was administered in fresh drinking water which was served to the birds on a daily basis during the period of study (Pandit et al., 1979).

\section{Ethanolic Leaf Extract}

Extraction of the dried leaves was performed by soaking the plant material in ethanolic alcohol $(70 \%)$ for $24 \mathrm{~h}$ in bath water $\left(37^{\circ} \mathrm{C}\right)$ then put the mixture in electric stirrer for $1 \mathrm{~h}$ next, the solution filtration by using Whitman's filter paper. The filtered distribute in tubes of centrifuge for 15 minutes. The clear liquid was putting in small glasses dishes and then set into the oven at $\left(37^{\circ} \mathrm{C}\right)$ for dried. after drying the extraction scrape off and dissolving in sterile distilled water. The product was kept in closed flasks and put in the icebox for the time of using (Harbone, 1973).

\section{Statistical analysis}

All data collected were subjected to one-way analysis of variance (ANOVA). Based on the Completely Randomized Design (CRD) using statistical package for the social science (SPSS, 2009). They were separated using Duncan's Multiple Range Test at 5\% level of probability $(\mathrm{P}<0.05)$.

\section{Results \& Discussion}

\section{Immunological parameters:}

The primary organs of immune system are bursa of fabricious and thymus, reached their maximum size of chicks about four weeks after hatching and then undergo gradual involution(Tizard, 1995). The finding obtained in this study (Table 3) showed that the birds fed them moringa treatments had a reduction in bursa relative weights which recorded the lowest weights of this glands among (0.067-0.073) \% in comparison with the control group that had the higher relative weight of bursa gland (0.077) \%. This reduction may reflect the good health and natural condition of birds and also for the reason of low mortality percentage or as a result effect of addition $M$. oleifera as natural growth promoter (Guo, 2003). This result was in agreement with the study of Nkukwana et al. (2014) who found significant differences $(\mathrm{P}<0.05)$ in bursa relative weights. Also, the present study were in line with Kumar et al. (2018) which notice a significant decrease in the weight of bursa gland reached $1.60 \mathrm{gm}$ when increasing the level of MOLM in diets to $20 \%$.However, it was not agreed with the findings of Khan et al. (2017). The present results showed no significant differences in spleen relative weights. This result was similar to other studies that not found any significant influence on the relative weights of spleen such as Ayo-Ajasa et al. (2016) and Alabi et al. (2017); while it was inconsistent with Onunkwo \& George (2015) who reported variance between moringa treatments and control group. The addition of MOLM, MALE, and MELE to the diets and drinking water of birds showed no significant effect on the percentage of heterophils to lymphocytes $(\mathrm{H} / \mathrm{L})$ between all study treatments. This result was not compatible with the study of Kwari et al. (2017) which observed significant differences between all groups of birds which bred in a semi-arid environment and fed M. oleifera leaf meal and Baobab as replacement for synthetic premix. 
Hussein \& Jassim /Basrah J. Agric. Sci., 32(Spec. Issue 2): 272-282, 2019

Table (3): Effect of $M$. oleifera leaf meal and their aqueous and ethanol leaf extracts on immunological parameters of broiler chickens (Mean \pm SE).

\begin{tabular}{ccccccccc}
\hline Parameters & $\mathrm{T} 1$ & $\mathrm{~T} 2$ & $\mathrm{~T} 3$ & $\mathrm{~T} 4$ & $\mathrm{~T} 5$ & $\mathrm{~T} 6$ & $\mathrm{~T} 7$ & S.L \\
\hline Bursa & $0.077 \mathrm{a} \pm$ & $0.070 \mathrm{bc} \pm$ & $0.071 \mathrm{bc} \pm$ & $0.072 \mathrm{bc}$ & $0.073 \mathrm{ab}$ & $0.067 \pm \mathrm{c}$ & $0.068 \pm \mathrm{c}$ & $*$ \\
glandweight & 0.003 & 0.004 & 0.071 & \pm 0.002 & \pm 0.002 & 0.003 & 0.002 & \\
$(\%)$ & & & & & & & & \\
\hline Bursa gland & $1.000 \mathrm{a} \pm 0.000$ & $0.911 \mathrm{~b} \pm 0.07$ & $0.922 \mathrm{ab}$ & $0.936 \mathrm{ab}$ & $0.949 \mathrm{ab}$ & $0.871 \mathrm{~b} \pm 0.05$ & $0.881 \mathrm{~b} \pm$ & $*$ \\
index & & 7 & \pm 0.011 & \pm 0.055 & \pm 0.032 & 4 & 0.024 & \\
\hline Spleen & $0.147 \pm 0.027$ & $0.117 \pm 0.005$ & $0.171 \pm 0.047$ & $0.158 \pm$ & $0.142 \pm$ & $0.155 \pm 0.051$ & $0.136 \pm$ & $\mathrm{NS}$ \\
$(\%)$ & & & & 0.027 & 0.017 & & 0.023 & \\
\hline H / L & $0.550 \pm 0.135$ & $0.520 \pm 0.161$ & $0.540 \pm$ & $0.460 \pm$ & $0.470 \pm$ & $0.490 \pm 0.098$ & $0.500 \pm$ & $\mathrm{NS}$ \\
& & & 0.095 & 0.089 & 0.082 & & 0.108 & \\
\hline
\end{tabular}

${ }^{a b c}$ Means in the same row with different superscripts were significantly different $(\mathrm{P}<0.05)$.

T1 (control without addition), T2 adding $2 \mathrm{~g}$ M. oleifera leaf meal (MOLM)/ $\mathrm{kg}$ of feed, T3 adding $4 \mathrm{~g}$ (MOLM) $\backslash \mathrm{kg}$ of feed, T4 adding $2 \mathrm{ml}$ Aqueous Leaf Extract (MALE) each 1 litre water, T5 adding $4 \mathrm{ml}$ (MALE) each 1 litre water, T6 adding $2 \mathrm{ml}$ Ethanolic Leaf Extract (MELE) each 1 litre water, T7 adding $4 \mathrm{ml}$ (MELE) each 1 litre water

\section{Liver enzymes}

The liver enzymes (AST \& ALT) are playing essentially role in the biotic process by transfer amino group from amino acids to ketone acids inversely in most of a live organism (Ibrahim \& Saleh, 2005). If the values of these enzymes were reduced that mean the birds in a good health because the livers were not in the case of stress. The values of (AST \& ALT) will be high in case of death of cells and damage of tissues (Aldaraji et al., 2008). The findings of the table (4) indicated that there was no significant difference in values of liver enzymes (AST and ALT) among groups of bird treated with $M$. oleifera and the control which free from any addition. This maybe reflects the natural function of intestines and liver of the birds (Melesse et al., 2013). The reason maybe as result to the addition a few levels of leaf meal, aqueous and ethanolic extracts, and thus not happen any impact on liver excretions from enzymes. This result was in agreement with the study of Olugbemi et al. (2010). Also, the values of AST and ALT were natural and without any negative effects on the experiments birds which added to their diets graded levels of cassava and moringa leaves (Aderemi \& Alabi, 2013).

Table (4): Effect of M. oleifera leaf meal and their aqueous and ethanol leaf extracts on liver enzymes of broiler chickens (Mean \pm SE).

\begin{tabular}{|c|c|c|c|c|c|c|c|c|}
\hline $\begin{array}{c}\text { Parame } \\
\text { ters }\end{array}$ & T1 & T2 & T3 & T4 & T5 & T6 & T7 & S.L \\
\hline $\begin{array}{c}\text { AST } \\
\text { IU/L }\end{array}$ & $25.50 \pm 0.53$ & $25.29 \pm 0.80$ & $26.50 \pm 0.83$ & $25.74 \pm 0.80$ & $26.42 \pm 0.53$ & $24.90 \pm 0.67$ & $26.46 \pm 0.47$ & NS \\
\hline $\begin{array}{c}\text { ALT } \\
\text { IU/L }\end{array}$ & $13.92 \pm 0.86$ & $12.68 \pm 0.80$ & $13.17 \pm 0.75$ & $12.93 \pm 0.64$ & $13.23 \pm 0.84$ & $12.82 \pm 0.78$ & $13.12 \pm 0.80$ & NS \\
\hline
\end{tabular}

T1: control without addition, T2: adding $2 \mathrm{~g}$ M. oleifera leaf meal (MOLM) $\backslash \mathrm{kg}$ of feed, T3: adding $4 \mathrm{~g}$ (MOLM) $\backslash \mathrm{kg}$ of feed, T4 adding $2 \mathrm{ml}$ Aqueous Leaf Extract (MALE) each 1 litre water, T5 adding $4 \mathrm{ml}$ (MALE) each 1 litre water, T6 adding $2 \mathrm{ml}$ Ethanolic Leaf Extract (MELE) each 1 litre water, T7 adding 4 ml (MELE) each 1 litre water . 
Hussein \& Jassim /Basrah J. Agric. Sci., 32(Spec. Issue 2): 272-282, 2019

\section{Conclusions}

From the results obtained in this study, we can conclude that the Moringa olivera plant meal $2 \mathrm{~g} . \mathrm{Kg}^{-1}$ can be used of feed and leaf aqueous and ethanol extracts at the level of 2 $\mathrm{ml}$ of drinking water in broiler meals and drinking water without harmful effects on the immune system and liver enzymes.

\section{Acknowledgments}

The authors wishes to thank Dean of College of Agriculture, University of Maysan Dr. Bashar J. Jomaa, and Staff of Department of Animal Production for their support.

\section{References}

Aderemi, F. \& Alabi, O. (2013). Effects of graded levels of Cassava peels fortified with Moringa as a replacement to wheat bran on performance, digestibility and blood profile of broilers. J. Agric. Sci. Technol., 3(23): 210-215.

Agashe, J.L.; Manwar, S.J.; Khose, K.K. \& Wade, M.R. (2017). Effect of supplementation of Moringa oleifera leaf powder on growth performance of broilers. J. Poult. Sci. Technol., 5(3): 28 - 34.

Alabi, O.J..; Malk A.D.; Ng'ambi, J.W.; Obaje, P. \& Ojo, B.K. (2017). Effect of aqueous Moringa oleifera (Lam.) leaf extracts on growth performance and carcass characteristics of hubbard broiler chicken. Braz. J. Poult. Sci., 19: 273-280.

Alcicek, A.; Bozkurt, M. \& Çabuk, M. (2003). The effect of an essential oil combination derived from selected herbs growing wild in Turkey on broiler performance. S. Afr. J. Anim. Sci., 33(2): 89-94.

Aldaraji, H.; Alhayani, W.Kh. \& Alhusseni, A.S. (2008). Physiology of Birds Blood. Univ. Baghdad Printing. Baghdad: 578pp.
Alfayaz, H.A. \& Naji, S.A. (1989). Poultry Product Technology. $1^{\text {st }}$ edn. High Educ. Direct. Press. Baghdad. (In Arabic).

Alikwe, P.C.; Iduah, T.S.; Elijah, I.O. \& Mathew, O.A. (2016). Effect of Moringa oleifera leaf meal as feed additive on layers performance. Biotech. Res. J., 2(1): 44-47.

Anwar, F. \& Bhanger, M.I. (2003). Analytical characterization of Moringa oleifera seed oil grown in temperate regions of Pakistan. J. Agric. Food Chem., 51: 6558-6563.

Ayo-Ajasa ,O.Y.; Abiona, J.A.; Fafiolu, A.O.; Egbeyale, L.T.; Njoku, C.P.; Omotayo, I.G.; Odeyemi, A.Y. \& Abel, F.A.S. (2016). Performance characteristics of broilers fed graded levels of Moringa oleifera leaf meal. J. Anim. Sci., 19(1): 2331

Bosch, C.H.; Moringaoleifera Lam. In: Grubben, G.J.H.; Denton, O.A. (Eds). PROTA, (2004). Plant Resources of Tropical Africa/ Ressourcesvégétalesdel'Afriquetropicale), Wageningen, Netherlands.

ElBanna, H.A.M. \& Atef, Gh.N. (2016). Anti coccidial activity of Moringa oleifera Plant. Anim. Vet. Sci., 4(2): 19-25.

FAO. (2014). Moringa. Traditional Crop of the Month. Rome: ???pp.

Fasuyi, A.O.; Dairo, F.A.S.; Adeniji, A.O. (2008). Tropical vegetable (Amaranthus cruentus) leaf meal as alternative protein supplement in broiler starter diets: bionutrional evaluation. J. Cent. Eur. Agr., 9(1): 23-24.

Francis, G.; Makkar, H.P.S.; \& Becker, K.; (2005). Products from little researched plants as aquaculture feed ingredients. Retrieved February 24, 2005. http:/www.fao.org.

Gbasi, S.; Nwobodo, E. \& Ofili, J.O. (2000). Hypocholesterolenic effects of crude 
extract of leaf of Moringa oleifera Lam. in high fat diet fed wistar rats. J. Ethnopharmacol., 69(1): 21-25.

Guo, F.C. (2003). Mushroom and herb polysaccharides as alternative for antimicrobial growth promoters in poultry. $\mathrm{Ph}$. D. Thesis, Wageningen Institute of Animal Sciences, Univ. Wageningen: 281pp.

Ibrahim, K.A. \& Saleh, E.S. (2005). Response of male broiler chicks to skip a day feeding programs. Egypt. Poult. Sci., 25: 351- 357.

Haruna, U. \& Hamidu, B.M. (2004). Economic analysis of Turkey production in the western Agricultural zone of Bauchi State. Proc. $9^{\text {th }}$ Annul. Conf. Anim. Sci. Assoc. Nig. (ASAN), 3: 299-303.

Harbone, J.B. (1973). Pytochemical Methods A Guide to Modern Techniques of Plant Analysis: Springer Science + Business Media B.V.: 302pp.

Hassan, K.U.; Khalique, A.T.; Pasha, N.; Akram, M.; Mahmood, S.; Sahota, A.W.; Imran, M.S. \& Saleem, G. (2017). Influence of Moringa oleifera decorticated seed meal on broiler performance and Immunity. Pak. Vet. J., 37(1): 47-50.

Khalafalla, M.M.; Abdellatef, E.; Dafalla, H.M.; Nassrallah, A.A.; Aboul-Enein, K.M. \& Lightfoot, D.A. (2010). Active principle from Moringa oleifera Lam Leaves effective against two leukemias and a hepatocarcinoma. Afr. J. Biot., 9(49):8467-8471.

Khan, I.; Zaneb, H.; Masood, S.; Yousif, M.S.; Rehman, H.F. \& Rehman, H. (2017). Effect of Moringa oleifera leaf meal powder supplementation on growth performance and intestinal morphology in broiler chickens. Anim. J. Physiol. Anim. Nutr., 101(S1): 1-19.

Kind, P.R.N. \& King, E.J. (1954). Estimation of plasma phosphate by hydrolysed with amino-antipyrine. Am. J. Clin. Path., 7: 322-326.

Kumar, A.; Kaushlendra, K.; Sangay, K.; Pankaj, K.S.; Jitendra, K.P. \& Chandramoni, (2018). Effect of feeding Moringa oleifera leaf meal on production efficiency and carcass characteristics of vanaraja chicken in tropics. Int. J. Curr. Microbiol. Appl. Sci. 7(Spec. Issue): 12131220.

Kwari, I.D.; Medugu, C.I.; Igwebuike, U.; Augustine, C.; Madu, W.J. \& Ibrahim, A. (2017). Growth performance, haematological parameters and serum biochemical indices of broiler chickens fed Baobab (Adansonia digitata) and Moringa (Moringa oleifera) leaf meals as replacement for synthetic premix in a semi- arid environment. J. Sci. Eng. Res., 4(12): 17-23.

Luqman, S.; Srivastava, S.; Kumar, R.; Maurya, A.K. \& Chanda, D. (2012) Experimental assessment Moringa oleifera leaf meal and fruit for its antistress, antioxidant and scavenging potential using in vitro and in vivo assays. EVID-BASED Compl. Alt., 2012: 12pp. DOI: 10.1155/2012/519084.

Mahmood, S.; Hassan, S.; Ahmed, F.; Ashraf, M.; Alam. M. \& Muzaffar, A. (2005). Influence of feed withdrawal for different durations on performance of broiler in summer. Int. J. Agric. Biol., 7: 975-978.

Makkar, H.P.S. \& Becker, K. (1997). Nutrients and antiquality factors in different morphological parts of Moringa oleifera tree. J. Agric. Sci., 128: 311-322.

Makker, H.P. \& Berker, K. (1996). Nutritional value and antinutritional component of whole and extracted Moringa oleifera leaves. Anim. Feed Sci. Tech., 63: 211228. 
Makker, H.P.S. \& Becker, K. (1999). Plant toxins and detoxification methods to improve feed quality of tropical seeds review. Asian-Aust. J. Anim. Sci., 12(3): 467- 480.

Melesse, A.; Yoseph,G.; Kefyalew, B. \& Sandip, B. (2013). Effect of feeding graded levels of Moringa stenopetala leaf meal on growth performance, carcass traits and some serum biochemical parameters of koekoek chickens. Live Stock Sci., 157: 498-505.

Moyo, B.; Oyedemi, S.; Masika, P.J. \& Mucheje, V. (2012). Polyphenolic content and antioxidant properties of Moringa oleifera leaf extracts and enzymatic of liver from goats supplemented with Moringa leifera leaves/sunflower seed cake. Meat Sci., 91: 441 - 447.

National Research council (NRC). (1994). Nutrient Requirement of Poultry. $9^{\text {th }}$ rev. edn. National Academy Press, Washington, D. S: 157pp.

Naji, S.A. (1996). Isolation immunologic globulin from blood plasma and egg yolk and study their activity against fever of Cambouro and Newcastle in broiler chickens. Thesis. Coll. Agric. Univ. Baghdad: (In Arabic).

Nickon, F.; Saud, Z.A.; Rehman, M.H. \& Hague, M.E. (2008). In vitro antimicrobial activity of the compound isolated from chloroform extract of Moringa oleifera Lam. Pak. J. Biol. Sci., 22: 1888-1890.

Nkukwana, T.T.; Muchenje, V.; Pieters, E.M.; Asika, P.J.; Mabusela, T.P.; Hoffman, L.C. \& Dzama, K. (2014). Effect of Moringa oleifera Leaf Meal on growth performance, apparent digestibility, digestive organ size and carcass yield in broiler chickens. Live Stock Sci., 161: 139 -146.

Ogbe, A.O \& John P.A. (2012). Effect of Polyherbal Aqueous Extracts Moringa oleifera, gum Arabic and wild antibiotic on growth performance and haemto logical parameters of broiler chickens. Res. J. Recent Sci., 1(7): 10 -18.

Olugbemi, T.S.; Mutayoba, S.K. \& Lekula, F.P. (2010) Effect of Moringa (Moringa oleifera) inclusion in cassava based diets fed to broiler chickens. Int. J. Poult. Sci., 9(4): 363-367.

Onunkwo, D.N. \& George, O.S. (2015). Effect of Moringa oleifera leaf meal on the growth performance and carcass characteristics of broiler birds. IOSR. J. Agric. Vet. Sci., 8(3): 63-66.

Onyimonyi, A.E. \& Onu, E. (2009) An assessment of pawpaw leaf meal as protein ingredient for finishing broiler. Int. J. Poultry Sci., 8(10): 995-998.

Pandit, N.N.; Singh, J. \& Bhattacharjee, D.K. (1979). Impact of feeding chakwar (casiatora) seed on growth of broilers. J. Poult. Sci., 14: 176.

Radovic, T. (2013). Farm and Forestry Production and Marketing Profile for Moringa In: Elevitch, C.R. (Ed.). Speciality Crops for Pacific Island Agroforestry, Permanent Agriculture Resources (PAR), Holualoa, Hawaii. Rural Development, 118, 22. Article\# www.lrrd.org/lrrd22/6/olug22118.htm.

Reitman, S. \& Frankel, S. (1975). Colorimetric methods for the determination of serum oxaloacetic and glutamic pyruvic transaminase. Am. J. Clin. Path., 28: 56-63.

Richter, N.; Siddhuraju, P. \& Becker, K. (2003). Evaluation of nutritional quality of moringa (Moringa oleiferaLam.) leaves as an alternative protein source for Nile tilapia (Oreochromis niloticus L.). Aquaculture, 217(1): 599-611.

Shen, P.F. \& Patterson, L.T. (1983). A simplified wrights stain technique for 
Hussein \& Jassim /Basrah J. Agric. Sci., 32(Spec. Issue 2): 272-282, 2019

routine avian blood smear staining. Poult. Sci., 62(5): 923-924.

Siddhuraju P. \& Becker K. (2003). Antioxidant properties of various solvent extracts of total phenolic constituents from three different agroclimatic origins of drumstick tree (Moringa oleifera Lam.) leaves. J. AGR. Food Chem., 51(8): 21442155.

Soetan, K.O. \& Oyewole, O.E. (2009). The need for adequate processing to reduce the anti-nutritional factors in plants used as human foods and animal feeds: A review. Afr. J. Food Sci., 3(9): 223-232.

SPSS. (2009). Statistical package of Soc. Sci., Ver. 18. Appl. Guide. copy Right by SPSS Inc.
Sreelatha, S. \& Padma, P.R. (2009). Antioxidant activity and total phenolic content of Moringa oleifera leaves in two stages of maturity. Plant Food Hum. Nutr., 64: 303-311.

Teixeira, E.M.B.; Carvalho, M.R.B.; Neves, V.A.; Silva, M.A. \& Arantes-Pereira, L. (2014). Chemical characteristics and fractionation of proteins from Moringa oleifera Lam. Leaves. Food Chem., 147: 51-54.

Tizard, I.R. (1995). Immunology; An Introduction. Saunders College Publisher, New York. 